\title{
Management in the early days of the Irish Free State: Bennetts of Ballinacurra
}

Research Article

\author{
Desmond Gibney ${ }^{1,2 *}$ and Martin Quinn ${ }^{1}$ \\ 'National College of Ireland, Dublin, Ireland \\ ${ }^{2}$ Dublin City University Business School, Dublin, Ireland
}

\begin{abstract}
This study details the management practices of a malting business called Bennetts of Ballinacurra (Bennetts), from approximately 1920s to the mid-1930s, a period when the Irish Free State was in its infancy. There is little extant literature on the management practices of Irish businesses of the time. Archival records, containing the company's books, records and correspondence, were our primary source. Our findings revealed a relatively sophisticated management information system for which its merchant background and close connections to Arthur Guinness \& Sons Ltd. (Guinness) were a potential explanatory factor. In addition, despite the business being small, the study revealed how management coped with issues such as business structure and industrial relations in a time of great political and economic change. There is scope for future research to utilise the archives of Bennetts, as well as other archives identified in our study.
\end{abstract}

Keywords: management practice; Irish Free State; Guinness

(C) De Gruyter Poland Sp. z 0.0.

\section{INTRODUCTION}

Studies of the internal workings of Irish businesses around the time of the formation of the State in the 1920s are scarce. Currently, about 100 years from a rebellion which brought about the State, this paper explores one such company, Bennetts of Ballinacurra (Bennetts). Founded in 1792, it continued as an independent family malting business until acquisition by Arthur Guinness \& Sons Ltd. (Guinness) in 1951. In the early twentieth century, Bennetts were at the forefront of efforts to improve the quality of barley breeding in Ireland. This suggests a strong management team and supporting infrastructure, which makes the case an interesting one to obtain a view of the state of management in this vital area of economic activity for Ireland.

There is little extant research on Irish businesses and management practices during the time period noted earlier. Thus, this study is somewhat exploratory in nature. As suggested by Quinn (2014), historical studies (of accounting in his case) offer interesting insights into the current-day state of organisational practices. Thus, this study explores the activities of Bennetts during the 1920s and 1930s, drawing on records at the Cork City and County Archives. This period was one where the fledgling Irish State endeavoured to set up new institutions of government, pass laws and develop economic policy. At the time, what we might today call professional management was likely to be less common in Irish business in general. However, we have little evidence to support such an assertion, and we hope this study provides some insights.

This paper is structured as follows. The next section outlines our approach, methods employed, a brief history of Bennetts and our intended contribution. Then, we provide a review of extant literature on management practices in an Irish historic context, as well as literature relevant to the malting sector business. This is followed by our findings on the management practices of the business. Two particular aspects emerged as important over the time frame. First, the choice of business structure, which was influenced by a preoccupation with the adoption of limited liability status for succession planning reasons; second, industrial relation problems, which were confronted in the absence of any formalised personnel/human resource management. Both aspects were influenced by the strength of the firm's connections with and reliance on Guinness. Although we do not draw on any theoretical lens per se to frame our findings, we do draw on concepts set out in prior literature to offer some interpretation in the final section and discuss some limitations as well as scope for further research. 


\section{APPROACH}

This study adopts an inductive approach, attempting to answer the typical question posed by Silverman (2013) What is going on here? - in a long-established family business. Colli et al. (2013: 849) observed that 'history is about variety, which is implicit in history's emphasis on inductive, more than deductive, research methodologies' and drew attention to the 'wide variety of sources that historians are able to use' (2013: 849). Given the topic of this study, this section outlines our use of archival records to research a business management topic, provides a brief history of Bennetts and outlines our intended contribution.

\section{Archival research}

Our justification for using an archival research method adopts to some extent the maxim of Platt (1981: 35) that a researcher 'must use what he can get'. Given the time period of the study, any nondocumentary method is likely to bear little fruit. We are thus limited to primary sources such as archives and/or to secondary sources such as extant literature - which as noted is scarce. Thus, archival data are our main source. It can reveal rich data, and Scott (1990: 15-16) observed that personal documents of 'wealthy and well-known families' were produced 'before the distinction between the personal and official was institutionalised'. Armstrong (1991) noted that very few companies maintained an archive, and the companies that did, tended to be large companies, which may bias any sample. In Ireland, while Ó hÓgartaigh (2008) noted many archival sources, they were rather underutilised, with the possible exception being the Guinness archive. Scott (1990: 15-16) noted 'if a researcher "discovers" a document in an archive and regards it as important source material it may be commercially published and thus become more readily available to other researchers'. In further support of our approach, Penrose (2009) emphasised the importance of the historical process and the value of using specific case studies, while Williamson (1981) noted the relative neglect of the business history approach in organisational studies. In essence, the records which we explore are reflective of what Scott (1990) termed recurrent and special administrative records and are ideal to form a picture of management at Bennetts. Scott (1990) described recurrent records as a necessary part of the daily operations and, consequently, they are embedded deep in the practices of the organisation; special records are reflective of ad hoc situations and requests. Other examples of studies that used recurrent records include Quinn and Jackson (2014), Hiebl et al. (2015) and Quinn (2014). There are extant studies using a case study approach similar to that employed here: e.g. case studies of a brewery (Hiebl et al., 2015; Quinn, 2014; Quinn and Jackson, 2014); department stores (Jeacle and Walsh, 2008; Walsh and Jeacle, 2003); a financial institution (Drea, 2014); a soap manufacturer (Griffiths, 1995); a thread producer (Kininmonth, 2006); a confectionery manufacturer (Jones, 1984) and an industry sector (Quinn and Leavy, 2004).

\section{A brief history of Bennetts}

Ballinacurra is a small village near Midleton, Cork, and served as a port for Midleton. The business known as Bennetts of Ballinacurra dates from 1792, when a malthouse and quay were built. Ownership passed to William Hallaran Bennett in the 1850s and subsequently to his son John Hallaran Bennett (1862-1935) in 1885. ${ }^{1}$ When the latter took over the business, he was 'faced with the task of rescuing a firm, which was virtually on its knees' (West, 2006: 7). Bennett had no technical training, but the senior management in Guinness - a major customer - trusted and worked with him and led to 'innovations such as breeding of new strains of malting barley at Ballinacurra particularly suited to Irish conditions' (West, 2006: 7). This coincided with the realisation by Guinness that the quality of 'barley used for malting was as important as, or even more important than, the brewing process itself' (Dennison and MacDonagh, 1998: 94), and this led to the establishment by Guinness of a research department and involvement with suppliers in conducting scientific experiments to enhance barley yields and quality. Using the Gourvish and Wilson's (1994) classifications of malting firms, Bennetts operated as a sales (commission) maltster to Guinness; Figure 1 shows the flow of transactions between the two. As shown in Figure 1, this arrangement meant that Guinness did not deal with individual barley farmers and that Bennetts acted as a 'middleman' for Guinness.

Bennett played an active role in public and religious life in east Cork (West, 2006), as a justice of peace and as a trustee of Midleton College. He was a member of the Church of Ireland, serving on the select vestry for Midleton parish and on the diocesan board of education. His political outlook was unionist, and in 1916 he welcomed the imposition of martial law following the Easter rising. He later became a supporter of the Cumann na nGaedheal party, but noted in his diaries in the early 1932 the lack of canvassing on behalf of the party in his area, which foreshadowed a loss 
of power to Fianna Fáil in the 1932 general election. As already noted, Bennetts were almost entirely dependent on the contract with Guinness for malting of barley. Guinness was also historically regarded as having a close identification with the Church of Ireland (Hopkins, 2009) and having unionist sympathies (The Economist, 2014). However, our examination of the records of Bennetts (files of correspondence between Bennetts and Guinness and John H Bennett's diary) does not bear out any favouritism based on religious or political sympathies. Bennetts can be contrasted with another long-established family business, the Scottish papermaking company Alex Cowan \& Sons Ltd (Cowans), which was the subject of a historical study on the 'Protestant work ethic' of its owning family (McKinstry and Ding, 2013). Unlike Cowans, our study of the archives of Bennetts shows no evidence that the religion of the owners played a significant part in business decisions. Drea's (2014: 1111) study of Ulster Bank 'provides a unique case study of a solidly Protestant and Unionist financial institution operating successfully in an increasingly Catholic-dominated Irish Free State'. Drea (2014: 1113) noted the 'strong Protestant representation in the Irish Free State industrial establishment' and evidenced companies such as Ulster Bank, Guinness and Jameson and W\&R Jacob. Although a smaller company than those examples, Bennetts also conformed to the same characteristics noted by Drea.

Figure 1: Depiction of flow of transactions between Bennetts and Guinness

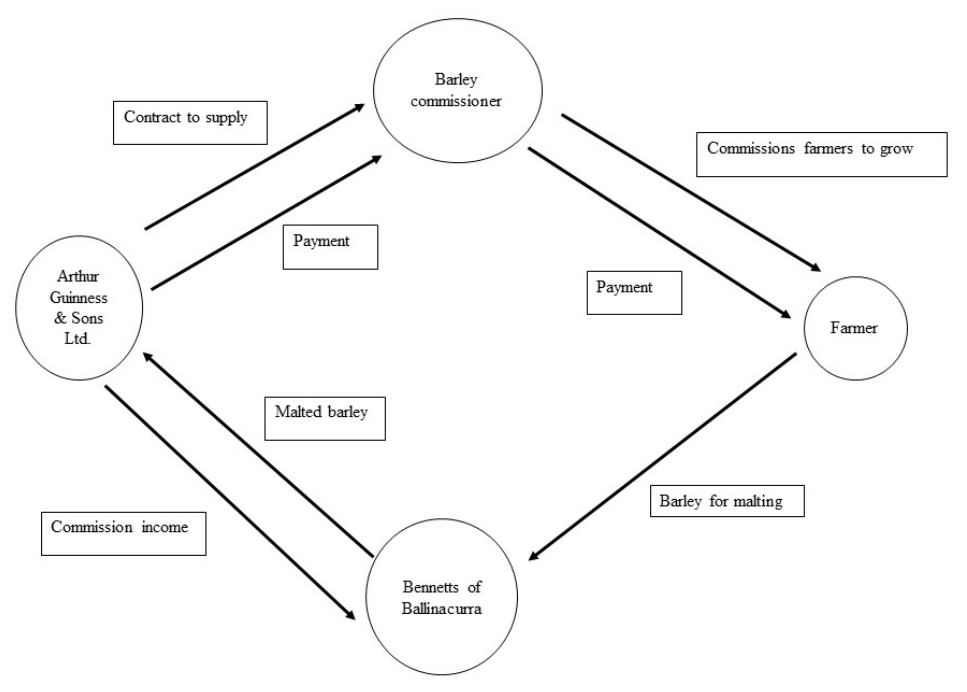

Bennett married Brida Williams in 1887, and they had two children: Jack (1890-1915) and Gwendoline (18911952). Brida died in 1916, and Bennett subsequently remarried to Esther MacNeill in 1918, who had a daughter, Dorothy. The family resided on the Charleston estate in Ballinacurra. Bennett headed the firm from 1885 until 1935 - which is within our study period - when his stepdaughter Dorothy West (née MacNeill) took over at the age of 30 years. Dorothy West ran the business until her retirement in 1969. Guinness acquired a majority shareholding in the company in 1951, acquiring the remaining shares in 1969. The business was purchased in a management buyout in 1996, eventually closing in 2006.

Key financial information for Bennetts is provided in Appendix 1. Extracts from the annual accounts of Bennetts from 1922 to 1935 are summarised in Table 1. The annual figures for income, net profit and dividends have been rebased to the current (i.e. 2015) values using Central Statistics Office (CSO) data (CSO, 2016) and are summarised in Table 2. ${ }^{2}$ These indicate that during the period of our review, and expressed in the current values, the business had an average annual income of $€ 670,000$ and average annual profits of $€ 165,000$, with average annual dividends of $€ 115,000$ after the formation of the limited liability company. Using the current legislative criteria, Bennetts would be classified as a small company (Government of Ireland, 2014). ${ }^{3}$ The figures show that while Bennetts was profitable, both income and net profit declined during this period, and the average annual rate of decline of net profit was twice as steep (4.8\%) as that of income (2.4\%). The decline can partly be explained by three factors (West, 2006). First, problems caused as a result of the Anglo-Irish Economic War from 1932 to 1938.4 Second, there was a dramatic decline in acreage under barley in the Midleton area. Third, Guinness fixed the price 
at which the barley was purchased; so while other maltsters such as Minch Norton were able to purchase barley in their own local areas, Bennetts had by 1935 to transport large amounts of barley to Ballinacurra for malting, making them less competitive than other maltsters.

Table 1: Extracts from accounts of John H Bennett \& Company Ltd (1928-1935) and John H Bennett (1922-1927)

\begin{tabular}{|c|c|c|c|c|c|c|c|c|c|}
\hline $\begin{array}{l}\text { Year to } \\
\text { August }\end{array}$ & $\begin{array}{c}\text { Income } \\
\text { per } \\
\text { Trading } \\
\text { Account }\end{array}$ & $\begin{array}{c}\text { Malting } \\
\text { Commission } \\
\text { (Included in } \\
\text { Income) }\end{array}$ & $\begin{array}{c}\text { Total } \\
\text { Malting } \\
\text { Expenses }\end{array}$ & $\begin{array}{l}\text { Audit } \\
\text { Fee }\end{array}$ & $\begin{array}{c}\text { Net } \\
\text { Profit } \\
\text { for } \\
\text { Period }\end{array}$ & $\begin{array}{c}\text { Preference } \\
\text { Dividend }\end{array}$ & $\begin{array}{l}\text { Ordinary } \\
\text { Dividend }\end{array}$ & Reserves & $\begin{array}{c}\text { Cash } \\
\text { and } \\
\text { Bank }\end{array}$ \\
\hline 1922 & $£ 16,448$ & $£ 16,357$ & $£ 11,018$ & $£ 21$ & $£ 5,423$ & NA & NA & NA & NA \\
\hline 1923 & $£ 9,819$ & $£ 9,698$ & $£ 7,502$ & $£ 21$ & $£ 2,242$ & NA & NA & NA & NA \\
\hline 1924 & $£ 12,020$ & $£ 11,947$ & $£ 2,015$ & $£ 26$ & $£ 2,015$ & NA & NA & NA & NA \\
\hline 1925 & $£ 12,695$ & $£ 12,410$ & $£ 10,474$ & $£ 54$ & $£ 1,967$ & NA & NA & NA & NA \\
\hline 1926 & $£ 13,796$ & $£ 13,616$ & $£ 10,545$ & $£ 34$ & $£ 3,091$ & NA & NA & NA & NA \\
\hline 1927 & $£ 12,853$ & $£ 12,834$ & $£ 9,462$ & $£ 28$ & $£ 3,390$ & NA & NA & NA & NA \\
\hline 1928 & $£ 13,119$ & $£ 12,955$ & $£ 7,723$ & $£ 21$ & $£ 5,396$ & $£ 0$ & $£ 0$ & $£ 1,631$ & $£ 382$ \\
\hline 1929 & $£ 12,460$ & $£ 12,054$ & $£ 8,588$ & $£ 21$ & $£ 3,630$ & $£ 300$ & $£ 0$ & $£ 4,961$ & $£ 2,769$ \\
\hline 1930 & $£ 12,396$ & $£ 12,046$ & $£ 9,710$ & $£ 21$ & $£ 2,685$ & $£ 300$ & $£ 1,000$ & $£ 5,495$ & $£ 1,289$ \\
\hline 1931 & $£ 12,764$ & $£ 12,403$ & $£ 10,391$ & $£ 21$ & $£ 2,373$ & $£ 300$ & $£ 1,000$ & $£ 6,678$ & $£ 161$ \\
\hline 1932 & $£ 10,382$ & $£ 9,902$ & $£ 8,064$ & $£ 30$ & $£ 2,318$ & $£ 300$ & $£ 3,500$ & $£ 4,281$ & $£ 1,647$ \\
\hline 1933 & $£ 9,601$ & $£ 9,012$ & $£ 7,573$ & $£ 25$ & $£ 2,027$ & $£ 300$ & $£ 2,500$ & $£ 3,038$ & $£ 2,808$ \\
\hline 1934 & $£ 9,581$ & $£ 8,702$ & $£ 6,633$ & $£ 25$ & $£ 2,486$ & $£ 300$ & $£ 1,250$ & $£ 3,594$ & $£ 2,271$ \\
\hline 1935 & $£ 9,915$ & $£ 8,976$ & $£ 7,454$ & $£ 40$ & $£ 2,360$ & $£ 300$ & $£ 1,750$ & $£ 2,257$ & $£ 1,549$ \\
\hline
\end{tabular}

Table 2: Extracts from accounts of John H Bennett \& Company Ltd (1928-1935) and John H Bennett (1920-1927) Converted to 2015 Values

\begin{tabular}{|c|c|c|c|c|c|c|}
\hline \multirow[t]{2}{*}{$\begin{array}{l}\text { Year to } \\
\text { August }\end{array}$} & \multicolumn{2}{|c|}{$\begin{array}{c}\text { Income } \\
\text { per Trading Account }\end{array}$} & \multicolumn{2}{|c|}{ Net Profit } & \multicolumn{2}{|c|}{$\begin{array}{l}\text { Total Dividends Paid } \\
\text { (i.e. Ordinary and Preference) }\end{array}$} \\
\hline & $\begin{array}{l}\text { In Nominal } \\
\text { Terms }\end{array}$ & $\begin{array}{l}\text { In } 2015 \\
\text { Terms }\end{array}$ & $\begin{array}{l}\text { In Nominal } \\
\text { Terms }\end{array}$ & $\begin{array}{l}\text { In } 2015 \\
\text { Terms }\end{array}$ & In Nominal Terms & In 2015 Terms \\
\hline 1922 & £16,448 & €841,236 & 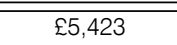 & €€277,360 & $\overline{\mathrm{NA}}$ & $\overline{\mathrm{NA}}$ \\
\hline 1923 & $£ 9,819$ & $€ 513,112$ & $£ 2,242$ & $€ 117,160$ & NA & NA \\
\hline 1924 & $£ 12,020$ & $€ 621,376$ & $£ 2,015$ & $€ 104,166$ & NA & NA \\
\hline 1925 & $£ 12,695$ & $€ 642,454$ & $£ 1,967$ & $€ 99,544$ & NA & NA \\
\hline 1926 & $£ 13,796$ & $€ 717,042$ & $£ 3,091$ & $€ 160,653$ & NA & NA \\
\hline 1927 & $£ 12,853$ & $€ 706,203$ & $£ 3,390$ & $€ 186,262$ & NA & NA \\
\hline 1928 & $£ 13,119$ & $€ 724,960$ & $£ 5,396$ & $€ 298,185$ & $£ 0$ & $€ 0$ \\
\hline 1929 & $£ 12,460$ & $€ 680,720$ & $£ 3,630$ & $€ 198,316$ & $£ 300$ & $€ 16,390$ \\
\hline 1930 & $£ 12,396$ & $€ 697,025$ & $£ 2,685$ & $€ 150,977$ & $£ 1,300$ & $€ 73,099$ \\
\hline 1931 & $£ 12,764$ & $€ 767,061$ & $£ 2,373$ & $€ 142,607$ & $£ 1,300$ & $€ 78,124$ \\
\hline 1932 & $£ 10,382$ & $€ 635,835$ & $£ 2,318$ & $€ 141,963$ & $£ 3,800$ & $€ 232,727$ \\
\hline 1933 & $£ 9,601$ & $€ 611,368$ & $£ 2,027$ & $€ 129,074$ & $£ 2,800$ & $€ 178,297$ \\
\hline 1934 & $£ 9,581$ & $€ 606,080$ & $£ 2,486$ & $€ 157,261$ & $£ 1,550$ & $€ 98,051$ \\
\hline 1935 & $£ 9,915$ & $€ 611,126$ & $£ 2,360$ & $€ 145,462$ & $£ 2,050$ & $€ 126,355$ \\
\hline
\end{tabular}

Note: The figures in Irish pounds from the annual accounts have been converted to 2015 values, using a base year of 1922 and then converted into euros.

\section{Methods employed}

The methods employed in this study are now detailed. The archival records of Bennetts, located in the Cork City and County Archives, are in good condition, clear and readily accessible. Ó hÓgartaigh (2008) noted that historians have engaged with business archives mainly in the areas of social and economic history, drawing on macroeconomic data, whereas micro-level resources can also cast new light on old historical problems. This study draws on the latter source type. To get a high level view on the business, we examined all areas of the business: correspondence sent and received, directors and management reports, employee agreements and wage rates, accounting books and ledgers, financial statements, barley purchasing records, other barley records and accounting-related correspondence. We also examined the personal diary of John $\mathrm{H}$ Bennett which provided brief commentary on the workings of the company. All records were examined over the period of 1920-1935. This time period covers the 
early years of the Irish Free State, a time when large businesses were not common in Ireland, and includes the early years of the Anglo-Irish Economic War. McCann (2014) noted that the Irish economy of the 1920s was still suffering the consequences of the War of Independence, the Civil War, partition between the industrially dominant north and the agriculturally dominant south, and was yet to face the consequences of the Great Depression of October 1929. The records were photographed digitally on-site and analysed both on-site and later. Where possible, business processes were traced through several books and/or files to ascertain the full nature of those processes - this mainly applied to accounting records. Recurrent records were the main source for our study, with some reference to special records (more details are given in the reference list). Copies of the Cork Examiner ${ }^{5}$ newspaper of the time period were also consulted at the National Library of Ireland (NLI). Once we examined the abovementioned records in some detail, a process of induction guided us to the most salient issues, which are outlined later.

\section{Contribution}

Brewing has long been an important industry in Ireland, and during the time period of our study, Daly (1992) noted that brewing accounted for $30.6 \%$ of net industrial output and $7.5 \%$ of employment in 1926 . There have been a number of historical accounting studies of Ireland's largest brewer, Guinness (Hiebl et al., 2015; Quinn, 2014; Quinn and Jackson, 2014). However, these studies have not ventured beyond the accounting realm. Malt is the main raw material for brewing (Gourvish and Wilson, 1994), and while the UK malting industry has been studied by Gourvish and Wilson (1994), Clark (1998) and Talbot (2006), it is relatively understudied compared to brewing. In an Irish context, the malting industry and indeed the brewing industry have been a relatively neglected area for academic research. In addition, in an Irish context, the relative lack of extant research on firms in general in the 1920s and 1930 s suggests that more could be done to contribute to our understanding of the historical management processes at this time.

\section{LITERATURE REVIEW}

This section details some extant literature on the history of management and management practices in Ireland and some of the broader literature on management practices after the First World War. After an initial review of literature relevant to the malting industry, we draw on elements of Henri Fayol's definition of management.

\section{Malting industry}

Before reviewing the literature on various areas of management practice, we turn first to the literature on the malting industry. The UK malting industry and its importance for the brewing industry have been studied by Gourvish and Wilson (1994), Clark (1998) and Talbot (2006) - Clark (1998) specifically focused on the sector. There are two main types of malting firms, according to Gourvish and Wilson (1994): sales maltsters who produce malted barley for brewers according to orders and brewers who malt themselves. Malting is significant as it is the brewer's 'main raw material and their profits from year to year depended on its price and quality' (Gourvish and Wilson, 1994: 185). Malting tends to occur in barley-growing areas and breweries chose to buy rather than malting their own barley because 'malting was an extremely space-consuming operation; labour costs were higher than in the countryside; and malt, lighter in weight than barley, was marginally cheaper to transport' (Gourvish and Wilson, 1994: 187). The purchase of the barley is often financed by the brewers, who then paid the maltsters 'for their working costs and profits ... what the brewer liked to do was deal with several maltsters in order to obtain the best malt, spread his risks, and keep the maltsters on their toes' (Gourvish and Wilson, 1994: 187). The malting contracts that were negotiated annually by the brewers 'imposed quality conditions and the growing power of the brewers over the malt suppliers allowed them to dominate the supply chain' (Talbot, 2006:198). As the brewers provided capital for the barley as well as other costs, the overheads of the maltsters were lower than otherwise (Talbot, 2006). The malting industry was regarded by Clark as being representative of many small business sectors, in that it was 'small-scale, family dominated and technologically unimpressive' (1998: 201). Clark noted that there are 'few sectors of the British economy where the participation of founding families was more enduring than in malting' (1998: 202). By the end of the First World War, most malting firms operated as partnerships; of firms that had converted to limited liability companies by the end of the nineteenth century, most were private companies (Clark, 1998). As we reveal later, Bennetts was family dominated and relatively small scale. 


\section{Studies of management practices}

This paper adopts a broad perspective on management, based on Henri Fayol's five elements of his definition of management, namely forecasting, organising, commanding, coordinating and controlling (Pugh and Hickson, 2007). Various writers, such as Gourvish and Wilson (1994), Clark (1998) and Talbot (2006), commented that practices in the malting industry were generally slow to change. Gourvish and Wilson (1994: 186) noted that, for some maltsters, 'the real test of their proficiency was in barley buying'. Talbot (2006: 325) commented that the continuity of production methods meant that there was a 'mostly successful adherence to traditional management practices'. Therefore, our review of the archival material for Bennetts has concentrated on elements of Fayol's definition of management that experienced change during the period of our study, as revealed through our inductive process. This in turn guided our literature review here. The two areas where change was apparent were organising (in particular, the topic of business structure) and commanding (in particular, the topic of industrial relations). In Fayol's definitions, organising refers to 'building up the structure, material and human, of the undertaking' and commanding refers to 'maintaining activity among the personnel' (Pugh and Hickson, 2007: 145). We also review some literature on accounting practices, as the nature of the business (a malting business) has implications for accounting practices, and these in turn affect business structure and succession planning. While acknowledging the limitations of studying a firm's accounts, Gourvish acknowledged (2006: 388-389) that the accounts 'attempt to express the impact of a complex web of activities as more precise measures' and 'whatever the numbers may be, there is a role for the business historian in making sense of them'.

\section{Studies of management practices: business structure}

Alfred Chandler is regarded as a foremost writer on the study of organisations, through his historical analysis of the period from 1850 to 1920, which he termed the 'formative years of modern capitalism' (Pugh and Hickson, 2007: 36). Chandler's influential book Scale and Scope (1994) studied growth and competitiveness in the US, Germany and the UK from the 1880s to the 1940s. Chandler (1994: 240) used the term 'personally managed enterprises' in relation to 'the governance of the enterprise' and to 'management "style" or, to use a more popular word, its management "culture"'. Chandler contrasted the prevalence of 'personal enterprises' found in UK business with the 'managerial capitalism' found in US business. These 'personal enterprises' were defined as being 'owner-controlled, frequently managed by founders or their families, and lacking extensive management hierarchies' (Church, 1990: 704) and were characterised by being owned/managed by families, who prioritised short-term income over longterm asset growth. Chandler concluded that the corporate structures typically found in British family firms were influenced by the goal of providing 'a steady flow of cash to owners - owners who were also managers' (Chandler, 1994: 390), and this resulted in high dividend payouts, low levels of retained profits and the issuing of preference shares and debentures, compared to managerial firms. However, Church (1990) cautioned against over-reliance on balance sheet data to support the arguments about the level of dividends and profits and also noted that 'by the very nature of personal enterprises after the first generation, owners tended to possess wealth, rendering income a welcome but less crucial objective' (1990: 706). In a response to Church (1990), Chandler (1990: 749) called for further studies of the 'role of retained earnings on the growth of enterprises'. In an Irish context, Quinn and Leavy (2004) studied the evolution of two Irish wholesaling industries, namely grocery and builders' merchants, since 1922. While their focus was on an industry rather than a firm, and on the role of government activism as an impetus for structural change in an industry, it does provide a demonstration of how case studies can be used to study neglected areas of business history. Quinn and Leavy (2004) noted the rise in prominence of trade associations during the protectionist era of the 1930s.

Church (1993: 30) noted that 'management succession has been widely acknowledged to pose particular problems for the longevity and performance of family firms'. The organisational structure of firms was studied by Gourvish (1987), who noted the importance of the general move by British firms to adopt limited liability status by around 1900, and the features of this trend included keeping the numbers of shareholders in individual firms small (with restrictions on share transfers) and control retained by families. According to Gourvish (1987), the principal reasons for limited liability status included concerns about future viability, desire for growth and personal or family circumstances of the business principal. A practical guide to conversion to limited liability companies was prepared by Palmer (1890), a barrister, and echoed the motivations noted by Gourvish (1987). According to Palmer (1890), the advantages of a limited company over a sole trader or partnership included the ability to obtain capital in consideration for a share in profits without incurring the liabilities of a partnership, and, continuance of a business in 
the event of the death or retirement of a partner/founder. Palmer (1890) also noted one circumstance where limited companies should preserve the typical rules of a partnership, namely where new partners could only be admitted with consent of all existing partners, as shares in a limited company could be transferred to any person unless the company's rules specifically prevented it.

\section{Studies of management practices: accounting practices}

There is some accounting literature that explores the general nature of the accounting profession in Ireland. Works by Clarke provide useful insights into the history of the Irish accounting profession. Clarke (1996) noted the lack of literature on Irish accounting history at that time, noting that 'the authorship of the first Irish accounting text may never be determined' (1996: 37). Clarke (2001) detailed the difficulties faced by the profession in the early years of independence - the analysis period of this study. A key issue was the lack of legislation in the newly independent state. He also noted the end of 'independent isolation' as Ireland enacted the Companies Act of 1963, the first major piece of company law in 40 years of independence.

There are few studies that provide a more detailed account of accounting practices (or management accounting) within Irish firms. There are many sets of archival records held in Ireland (Ó hÓgartaigh and Ó hÓgartaigh, 2004), many of which are unexplored. Having said that the literature that does exist is insightful. For example, Jeacle and Walsh (2008), building on Walsh and Jeacle (2003), provided extensive detail on how a retail price inventory method was applied by a Dublin-based department store - Arnotts - during the 1930s. This was, according to Jeacle and Walsh (2008), a valuable management control tool as well as an inventory valuation method. There are also a small number of studies that detail internal accounting practices at Guinness. For example, Quinn (2014) explored accounting change in the cooperage at Guinness over a 100 -year period from the 1880s. In a similar vein, Quinn and Jackson (2014) explored change to accounting practices at Guinness as influenced by the First World War. Finally, Hiebl et al. (2015) explored the role of the Chief Accountant at Guinness from 1920 to 1940, offering a view that this role was very similar to the modern-day chief financial officer (CFO). While these studies of Guinness are insightful, it should be noted that this company was one of a small number of large companies of the time, as the nascent Irish economy was mainly agricultural with the government not pursuing any policy of industrialisation until the early 1930s (Ó Gráda, 1997).

A study of accounting practices in the brewing sector (Walkden, 1891) noted that the accounting practices of maltsters may not follow good bookkeeping and accounting practice. Walkden (1891: 484) noted that 'a maltster seldom receives an invoice from a farmer - therefore the only evidence of correct settlement will be in the paid cheques which can be compared to the Barley Purchases Book'. Clark (1998) provided some details on costs and profits at British maltsters from the period 1830-1914. Her work suggested that costs of a malting were tracked and profit could thus be calculated. She also indicated an increasing focus on costs and accounting during and after the First World War, something echoed in the accounting literature (Loft, 1986).

\section{Studies of Management Practices: Management}

Daly (1992: 13) observed that 'the 1920s were not the most opportune decade for a newly independent nation. Wages and prices fell after wartime inflation; agriculture was depressed; unemployment, external competition, and technological change affected hitherto stable industries'. One of the few studies of management history set in the time frame of our study is Drea's (2014) study of Ulster Bank and provides a case study of how political factors influenced how this Northern Ireland-based bank operated in the Free State. Other studies that covered this time frame included examinations of how multinational companies such as Cadbury (Jones, 1984) and Woolworths (Walsh, 2011) operated overseas, but those studies had less relevance to the current study as they focused on multinational operations.

\section{Studies of management practices: industrial relations}

The typical characteristics of industrial relations in the sector were identified by Gourvish and Wilson (1994: 198), as continuity of employment and paternalism, and although malting remained a seasonal business, 'generation followed generation' of workers with 'remarkable instances of the longevity of individuals' service and the attachments of families'. Gourvish and Wilson also noted that the paternalism could be 'heavy handed' (1994: 198) in relation to attempts to unionise the workforce and that the continuity of employment in the brewing industry 'guaranteed workforces which, in comparison with those in other industries, were remarkably quiescent and constant' (1994: 200). 
In an Irish context, the history of wage bargaining in Ireland was influenced by the fact that 'huge increases in union membership in the 1910s had been followed by drastic declines in the 1920s' (Ó Gráda, 1997: 99). Developments in industrial relations and trade unionism were heavily influenced by events in Britain (Gunnigle et al., 2002). Among the significant developments in the early twentieth century, Britain was the 'Taff Vale' case of 1901 (Taff Vale Railway Company v. Amalgamated Society of Railway Servants, 1901) and the subsequent enactment of legislation dealing with picketing (Trade Disputes Act, 1906). The 'Taff Vale' case concerned violence during a strike, and while there was no evidence that the union had organised the violence, it was found liable and damages awarded to the company. The 1906 Act, 'often referred to as the "Bill of Rights for Workers", provided legal immunity for unions involved in strike activity and authorised peaceful picketing' (Gunnigle et al., 2002: 249), but did not provide a positive right to strike. The 1906 Act also did not make it illegal to sack striking workers, although selective dismissal of individuals was not permitted, nor was selective re-engagement. The 1906 Act therefore made possible the 1913 Lockout in Dublin. The dismissal of workers for striking has seldom been a feature of Irish industrial relations, so it rarely features in Irish industrial relations literature.

Monks (1997) dated the first appearance of personnel management in the Irish private sector to the establishment in Dublin in 1937 of an Irish branch of the Institute of Labour Management (ILM), the predecessor of the Institute of Personnel Management (IPM). ${ }^{6}$ The IPM was formed at a conference of employers in York, England, in June 1913, and one of the attendees was Charles Jacob a director of W\&R Jacob Ltd of Dublin. A history published to mark the 50th anniversary of the founding of the IPM in 1913 noted that the absence of a formal branch in certain geographic areas meant that 'the "scattered members" in Dublin or the North of Scotland or overseas, who could not join in the life of the branch still looked beyond their place of work to the wider social issues' (Niven, 1967: 67).

\section{MANAGEMENT PRACTICES OF BENNETTS}

The records of Bennetts reveal a relatively sophisticated management information system leading to good financial administration, detailed production controls ${ }^{7}$ and engagement in industrial relations practices. Given the relatively small size of the business, combined with the existence of archive material dating back to the $1820 \mathrm{~s}$, it is likely that the records that Bennetts maintained from its formation allowed it to manage the business as a whole and to maintain the quality of goods (McWatters and Lemarchand, 2013). Detailed records on barley may stem from this merchant background. As reflected earlier, two key issues emerged from our analysis of the management practices at Bennetts over the time period of our study - business structure and succession planning and industrial relations issues. Both of these are connected to, and impacted by, the relationship between Bennetts and Guinness, which is our starting point.

\section{'The Board confidently leaves the matter in your hands': relationship with Guinness'}

Bennetts was a long-standing supplier of malted barley to Guinness, and its importance was noted by Lynch and Vaizey (1960). Each year, Guinness notified Bennetts of the quantity of malt to be supplied. For example, the 1928/1929 requirements were conveyed to Bennetts as follows:

Our Board has been giving consideration to the question of our supplies of malt for the coming season and we now write to say that the quantity of malt which we wish you to manufacture is 28,500 barrels, and we enclose the usual form of agreement. (Letter from Guinness, 19 September 1928)

Guinness maintained a close interest in factors external and internal to Bennetts impacting the supply of malt. Depending on the circumstances, the stance of Guinness varied between requesting a particular course of action, offering advice or leaving the matter in the hands of Bennetts. On one occasion, during a time of uncertainty about the availability of coal supplies, Guinness asked Bennetts to store extra coal because a quantity of Welsh coal could be delivered at short notice, as 'the Board are rather uneasy about coal supplies having regard to the international situation' (Letter from Guinness, 27 July 1939). The 'international situation' mentioned in this letter referred to the developments that led to the Second World War shortly afterwards. On another occasion, Guinness noted the 'curious attitude of your local farmers to refuse anything below top prices' and Guinness suggested that Bennetts should stick to the average prices paid by Guinness and not to 'follow the farmers' tendency to hold out for top prices' (Letter to Dorothy West, 31 August 1940). 
On yet another occasion, during an industrial relations dispute in Bennetts, Guinness declined to express an opinion and decided that 'the Board ... confidently leave the matter in your hands' (Letter to John H Bennett, 13 December 1928). Bennett sometimes bridled at the restrictions placed upon him by Guinness, and this illustrates an unequal distribution of power in the relationship. For example, on one occasion, Bennett wrote in his diary that he received a 'severe rebuke' as he had allowed himself to be quoted as an agent of Guinness in a newspaper report on the barley market, without prior approval from Guinness. He observed that 'these incidents show how extremely restricted are one's actions and that no individuality is allowable' (Diary of John H Bennett, 28 October 1926).

As can be seen in the summary of Bennetts' financial statements (Appendix 1), almost their entire income derived from commission earned by malting for Guinness. This reliance on one source of income led Bennetts to decline some initiatives in which other businesses participated. For example, Bennetts declined to contribute funds for a candidate for election to Cork Corporation 'as we are not an independent trading firm we do not feel called upon to contribute to same' (Letter to Honorary Secretary, Cork Incorporated Chamber of Commerce and Shipping, 2 February 1929).

Following the election of Fianna Fáil to government in 1932, the Anglo-Irish Economic War emerged and continued until 1938 (Neary and Ó Gráda, 1991; O'Rourke, 1991). Partly as a result of the Economic War and the consequent increase in the cost of imports, Guinness built a brewery in the UK, although according to Dennison and MacDonagh (1998), the idea of a UK brewery was first mooted around 1913. Because of his company's dependence on Guinness, Bennett noted in his diary in August 1934 the 'prejudicial' effects that such a UK brewery would have on the Irish malting industry. Guinness opened its Park Royal brewery in London in $1936 .{ }^{8}$

\section{'A gentleman and a maltster': business structure and succession planning'}

The business was carried on as a sole trader under the name of John H Bennett until 1928. As of 4 April 4 1928, the business was incorporated as John $\mathrm{H}$ Bennett \& Company Ltd. Companies Office records show that the initial directors of the company were John $\mathrm{H}$ Bennett and his wife Esther Bennett. Of the 10,000 ordinary shares issued, 9,685 were issued to John $\mathrm{H}$ Bennett himself, with the balance to his wife and children. The latter also held preference shares. The company's lawyers, Exhams Solicitors, noted that Bennett was described as a 'maltster' on Form M45, whereas he was described as a 'gentleman' on the share register. The move to incorporation did cause some confusion. Guinness wrote in September 1928 to ascertain the correct form of address for future correspondence, noting Bennett's use on different occasions of the styles 'J.H. Bennett' and 'John H. Bennett Ltd.' and believed that "we ought always to address you now as "John $\mathrm{H}$. Bennett Limited", but after all these years I do not like to start writing to you as "Dear Sir"' (Letter from Guinness, 17 September 1928). The archive copy of this letter contains a handwritten note from Bennett stating that he also experienced difficulty in remembering the correct form of wording to use in his business letters.

The move to limited liability came about because Bennett was increasingly concerned about continuation of business as he had no male heir. Bennett had one son, Jack, who spent 7 years working with his father in the family business and 2 years working with another firm of maltsters, P.R. Norton, ${ }^{9}$ after completing his formal education. Unfortunately, Lieutenant Jack Bennett of the Royal Munster Fusiliers was killed in action in France in October 1915 (West, 2006). While Bennett's stepdaughter Dorothy West (née MacNeill) worked with him in the business, his daughter Gwendoline lived in England as she 'felt somewhat uncomfortable with a forceful stepmother now very much in control of domestic matters in Charleston and was happier to have a base elsewhere' (West, 2006: 99). Bennett worried that 'bringing a non-family member into the business would reduce the dividend payable to his wife and step-daughter and particularly to his daughter' (West, 2006: 102).

During the entire period of our study, AJ Magennis \& Company and Incorporated Accountants and Auditors, ${ }^{10}$ from Cork, were the preparers of the annual accounts (a summary of key figures is given in Appendix 1). From 1928 onwards, they also served as auditors of the company. Bennett received advice in 1927 from AJ Magennis \& Company to form a limited company. Among the main considerations were the liability being limited to the amount of paid-up share capital, and the private estate would be unaffected by the fortunes of the company. Another reason given was the power to restrict the transfer of shares to those who would be considered suitable to be shareholders:

In addition to the enjoyment of limited liability, the Directors of a private company have power to restrict the transfer of shares to those whom they consider fit and proper persons to hold shares in the company. This prevents anyone becoming a Shareholder who might be likely to cause trouble in the future. (Letter from AJ Magennis \& Company, 4 October 1927) 
Bennett was also advised about his own position in the business:

You should retain in your own name a majority of the Ordinary Shares to as to give you control, and you should be Chairman and Managing Director for life with an adequate salary. (Letter from AJ Magennis \& Company, 4 October 1927)

The accountants also advised Bennett about the capital structure of the limited company. They advised that if it was decided that the capital of the company should be $£ 15,000$, then $£ 10,000$ should be in the form of ordinary shares of $£ 1$ each and the remainder should be $£ 5,000$ of $10 \%$ preference shares. The stated reason for preference shares was that whoever was allocated preference shares would have an income of $£ 500$ per annum as first charge on the profits of the company, and in any year if profits after directors' fees should fall to $£ 1,000$, a preference dividend of $£ 500$ would be paid even though an ordinary dividend would not be paid. In the event, the capital of the company was fixed at $£ 15,000$ and was split between ordinary shares of $£ 10,000$ and preference shares of $£ 5,000$, although the percentage dividend for the preference shares was fixed at $6 \%$ per annum. ${ }^{11}$ The total of the company's first balance sheet total was $£ 17,214$ and the principal assets comprised premises and land $(£ 7,000)$, debtors ( $£ 3,067)$, goodwill $(£ 2,500)$, stock $(£ 2,267)$ and cash on hand and in bank ( $£ 382$ ). This was financed by ordinary share capital ( $£ 10,000$ of $£ 1$ shares), preference share capital ( $£ 5,000$ of $6 \% £ 1$ shares) and the balance on the profit and loss account $(£ 1,631)$. The goodwill was fully written off by 1936 . A preference dividend was paid from the year ended 1929 onwards, and an ordinary dividend was paid from the year ended 1930 onwards. The ordinary dividend started at $£ 1,000$ per annum for the first 2 years and increased subsequently, averaging $£ 2,000-£ 3,000$.

The decision to form the limited company was intended to safeguard the continuity of the business:

The fact that your capital in the business will be represented by Shares will facilitate the making of your will, whereas in a Partnership it is always difficult to make a proper disposition owing to the existence of another Partner. (Letter from AJ Magennis \& Company, 4 October 1927)

However, it became apparent after Bennett's death that there were difficulties in valuing the business for probate purposes. As Bennetts was a private company, its shares were not traded and this created a difficulty in reaching an agreed value. Two further factors specific to the circumstances of the formation of this particular company in 1928 prompted Bennett's stepdaughter to write to Guinness, because of the close connection between Bennetts and Guinness. Firstly, the nature of the brewing industry and the accounting practices associated with it (as described by Walkden, 1891) meant that:

This little firm is almost unique. Its dealings are really cash transactions. [...]. We have no reserve fund, practically no realisable assets, but we show over $£ 8,000$ per annum for the manufacture of malt, paid in cash. The Revenue Commissioners seem to be taking the line that our Commission has gone on for over 100 years, and presumably will continue. It is difficult to explain what the loss of Mr. Bennett's personality has meant. (Letter to Guinness from Dorothy MacNeill, 25 November 1935)

Secondly, there were also difficulties due to the low capitalisation of the company:

When the company was formed in 1928, my step-father insisted that the capital of the company be fixed at a very low figure, because he had seen too many Irish businesses burdened with too much share capital - e.g. the North of Ireland linen trade, and firms like Minch, Norton \& Co. At the time it was apparently a matter of book entries; any ordinary shares were in his hands (with the exception of a generous present to $\mathrm{me}$ ), and the profits would go to him as in the past. But the profits were out of proportion to the share capital, and appeared in the balance sheets as very large dividends. (Letter to Guinness from Dorothy MacNeill, 25 November 1935)

As noted earlier, Bennetts paid out substantial dividends after the formation of the company, which contributed to the low levels of equity reserve: 
Unlike most of his compatriots, my step-father put almost all his income back into the business, and invested little capital outside it [...].What is a very important factor is that there is no reserve fund whatsoever. Profits have been distributed entirely, and the assets of the company are the malting premises and machinery, extremely valuable to us at the moment, but in case of the withdrawal of the Commission realisable at scrap prices only. (Letter to Guinness from Dorothy MacNeill, 25 November 1935)

\section{'Recent Happenings in Connection with Labour': Industrial Relations Issues}

In some respects, Bennett was a benevolent employer who established a 'Workmen's Club' that operated from 1912 to 1926 and enabled staff who subscribed as members of the club to read daily newspapers, play card games and engage in other social activities (West, 2006). Bennett left $£ 1,000$ in his will to a trust for Ballinacurra workers to be administered by Mrs West (née MacNeill). However, the taxation authorities determined that as no actual trust had been created by Bennett's will; the 'trust' was regarded as income of his family.

In other respects, Bennett was an employer who was prepared to reduce the wage rates when necessary as noted by Clark (1998), labour cost was one of the substantial costs of malting. The records contained details of notices issued from time to time regarding alterations in the weekly wages of workmen, and one such record noted that the workmen were 'notified that they are employed from day to day only subject to deliveries of barley being sufficient to provide work'. Reductions in wages formed the background to a strike in the late 1928, the first strike in the company in over 100 years. Bennetts were a member of a representative body for the industry, the Irish Maltsters' Association, and there were a series of agreements between the association and the Irish Transport and General Workers' Union (ITGWU). For example, an agreement signed on 12 October 1922 provided a mechanism for wages to rise or fall in certain circumstances if there was a change in generally accepted cost of living measures. In line with action taken by the Irish Maltsters' Association, Bennett confirmed in October 1927 that the wage rates would be lower than in the previous year. On 6 December 1928, Bennett recorded in his diary that he 'received a most unexpected demand' from his maltsters for a wage increase and threatening a strike unless their demands were met. When 18 maltsters notified Bennett of their intention to strike, he paid them their wages to date and sacked them and refused offers of mediation until the malt had been harvested (West, 2006). The dismissal of striking workers was permitted under the Trade Disputes Act of 1906, and Bennett further complied with the provisions of that Act by not engaging in selective dismissal or selective re-engagement. Some of the senior employees decided to continue working during the strike:

The efforts of these men and the office staff would not be sufficient to continue the labour intensive floor malting process so Bennett appealed to his neighbours for volunteers. The response was excellent and a group of halfa-dozen ... turned up to support him. The volunteers were barracked by the strikers but the civic guard ${ }^{12}$ arrived $^{2}$ in numbers to quell any trouble. (West, 2006: 104)

Bennett also used his connections as vice-commodore of the Royal Munster Yacht Club (RMYC) to seek volunteers to help with the harvest, and 12 yachtsmen arrived on 11 December $1928 .{ }^{13}$ The arrival of the RMYC volunteers 'had an immediate impact on the morale of the workers' (West, 2006: 104).

While Guinness were not directly involved in the strike, they monitored closely the developing situation, and Bennett kept Guinness informed regularly by post and by telephone of all significant developments. Understandably, the focus of Guinness was on the maintenance of malt supplies and the quality of the production. For example, Bennett was 'congratulated on the fact that the strike has had so little effect upon the malt', but the same letter also requested a sample of the barley from the RMYC batch 'to be checked in our laboratory, as this was one which was entirely handled by volunteers' (Letter from Guinness to John H Bennett, 27 December 1928). Guinness wrote to Bennetts on 7 December 1928 and confirmed that they 'approve entirely' of the action taken by Bennett. A Guinness executive who was a member of the Irish Maltsters' Association and also was one of the negotiators of the wage agreements between the unions and the association 'offered his services if he can be of any use and is quite willing to undertake the journey to Cork at any time if you think he can be helpful' (Letter from Guinness to John H Bennett, 7 December 1928). However, on the following day Guinness wrote again:

The Board are unwilling to send you any help from here. The quarrel is between your Company and their employees. The fact that you have a contract with us which the action of your men will prevent you carrying out would hardly justify us in interfering actively. (Letter from Guinness to John H Bennett, 8 December 1928) 
Precise information about wages in the malting industry during the period of our study has been difficult to obtain. However, some information was provided in a letter from Guinness to John H Bennett on 10 December 1928, which set out the brewery's understanding of wage rates of Bennetts and of the Irish Maltsters' Association for the three seasons from 1926/1927 to 1928/1929, for two categories of worker, namely maltmen and loftmen. For the 1928/1929 season, for example, Bennetts paid a weekly wage of 52 shillings 4 pence and 40 shillings 1 penny to the maltmen and loftmen, respectively, while the corresponding wage rates for the Irish Maltsters' Association were 54 shillings and 41 shillings. In that letter, Guinness queried whether Bennetts' workers had been subjected to two reductions in their wages or three, and it has not been possible to determine what response was sent by Bennett. ${ }^{14}$

While Guinness declined to offer practical support during the strike, they continued to offer encouragement on 10 December 1928 and wrote that 'if it is any consolation to you in your trouble, you may like to know that the Board are very pleased indeed with the way in which you have handled this difficult matter' (Letter from Guinness to John H Bennett, 10 December 1928). That letter also queried the wage rates in Bennetts in recent years:

If your adoption in the Autumn of 1926 of the standard fixed by the Irish Maltsters' Association meant in the first instance a reduction of wages to the men and was followed by a fall .... each year afterwards, they may be excused for thinking that the Irish Maltsters' Association was an invention of the devil! Prior to 1927/28, the Irish Maltsters' Association standard had not been changed since 1922. (Letter from Guinness to John H Bennett, 10 December 1928)

Guinness also declined to advise Bennett on any further steps to take in this industrial dispute:

The Board consider that you have handled the matter so well up to the present that they would not like to express any opinion as to the way in which you should conduct negotiations with your men. You know the men and you know the local conditions and must be the best judge of how to handle the situation, so they confidently leave the matter in your hands. (Letter from Guinness to John H Bennett, 10 December 1928)

On 5 January 1929, some of the striking workers approached Bennett, offering to return to work on the previous wages. Bennett insisted that all 18 maltsters sign a written agreement on conduct in any future strikes. The agreement was signed by the maltsters and Bennett's diary entry for 7 January 1929 was brief: 'Work resumed after strike'. His diary entry for 2 days previously was slightly longer and put the strike into context: 'Thank God this trouble is over. The only strike that has occurred here in living memory - probably for 100 years' (Diary of John H Bennett, 5 January 1929). While Bennett expressed understandable relief when the strike was over, it seemed that some bitterness from the strike remained afterwards, as evidenced by Bennett's decision to decline to contribute to local hurling clubs:

In reply to your letter asking for a subscription to the Midleton Hurling Club, having regard to recent happenings in connection with labour in my establishment, I regret that I am not in a position to contribute to sports or amusement as formerly. (Letter to Honorary Secretary Midleton Hurling Club, 26 January 1929)

In reply to your appeal for subscriptions, I much regret that, owing to recent difficulties in the Maltings, I cannot contribute anything to the Club funds. (Letter to Honorary Secretary Ballinacurra Hurling Club, 29 February 1929)

The Cork Examiner newspaper reported (1929: 4) that while 'acute distress prevailed amongst the strikers' families' during the strike period, 'through the intervention of prominent local residents, an amicable agreement has been arrived at'. The contention of this newspaper report is supported by the fact that at the time of the strike, when Bennett's assistants were collecting payment from Ballinacurra villagers for milk supplied from Bennett's dairy, they 'did not receive a hostile reception' from villagers (West, 2006: 104). 


\section{DISCUSSION AND CONCLUDING COMMENTS}

The nature of the business of Bennetts was very merchant like, essentially harvested barley in and malted barley out, and the records show a heavy dependence on one company, namely Guinness. While the reliance on Guinness could be regarded as putting Bennetts in a somewhat vulnerable position, it was not our objective to examine how Guinness may have exerted its influence. As barley was purchased and paid for by the barley commissioners on behalf of Guinness, rather than by Bennetts, the costs borne by Bennetts were lower than they otherwise would have been. However, our analysis shows that the income and profits declined on average each year during the period of our study.

Our study reveals how a small company successfully dealt with what was for it an unprecedented industrial relations problem, and this took place almost a decade before Monks (1997) credited the first appearance of personnel management in the Irish private sector. Further, our study shows that the gap in legal protection for strikers highlighted by the 1913 Lockout still persisted in the early years of the Irish Free State. The company demonstrated the typical characteristics for that sector that were identified by Gourvish and Wilson (1994), namely continuity of employment and paternalism, but also demonstrated a determination to use whatever means were available to them, such as the use of volunteers brought in from a yacht club to carry out the work of striking workers during the busy harvest season. Our study also supports the finding of Quinn and Leavy (2004) about the importance of trade associations. Bennetts' membership of the Irish Maltsters' Association throughout the 1920s, for example in the lead-up to the strike of 1928-1929, demonstrates that trade associations were important prior to the 1930s, which was the period identified by Quinn and Leavy (2004). Our study also bears out the trend identified by Gourvish (1987) for the growing importance of private limited companies as opposed to other forms of business structure, although it did not ultimately provide the intended solution to the problem of business succession, as the firm also faced the difficulties of declining income and profits. The experience of Bennetts after incorporation as a limited company, together with the high level of dividends paid out to family members, supported the view of Chandler (1994) that decisions about business structure in family firms were influenced by the objective of providing cash to owner-managers.

As we stated at the outset, our study is exploratory in nature. A common thread across various aspects that we studied is the influence exercised by Guinness on Bennetts, and this is demonstrated most vividly in relation to the events surrounding the first strike in the firm's history in 1928-1929. Guinness were kept informed daily about developments in the strike, not least because a strike would have prevented Bennetts from honouring their malting contract, and the importance of malt as the main raw material for brewers cannot be understated (Gourvish and Wilson, 1994). Guinness offered to assist Bennetts in dealing with what was for Bennetts an unprecedented industrial relations problem and then declined to intervene in a dispute that Guinness regarded as being between Bennetts and their workers.

This study has some limitations and also presents some opportunities for future research. The first limitation, in common with archival research generally, is that we cannot be absolutely certain whether we have interpreted the actions behind all the records correctly. However, we have been able to examine different sources of information to strengthen our findings, e.g. correspondence to and from Guinness, and also the personal diary of John $\mathrm{H}$ Bennett. A second limitation is the scarcity of historical literature on the management practices of Irish firms. While this study offers some insights, it is based on a single case and thus may not be representative or generalisable. Further studies would shed light on management practices in the 1920s and 1930s in Ireland, and the work of O hÓgartaigh and Ó hÓgartaigh (2004) is a useful starting point, although their listing of archival records in Ireland does not extend to archives held in other sources - such as university libraries or city or county archives (such as the source here). Given the commercial relationship between Guinness and Bennetts and also the nature of family business, there is a potentially fruitful area of research on the topic of supply chain management and the research could be facilitated by the archive material available for both Guinness and Bennetts. As our study finishes around 1935, also there is a scope for further study of the Bennetts and Guinness archives to examine the impact of the Economic War from 1932 to 1938, and in particular the lead-in to the opening by Guinness of its Park Royal brewery in London in 1936. Other archival resources are available, such as the National Archives of Ireland, which contains archives acquired from sources such as business and professional firms. Privately held archives include the records of Eason and Son, Guinness and Irish Distillers. Finally, the Irish Labour History Society archives may provide additional perspective and context on the industrial relations issues highlighted during the period of our study. 


\section{ACKNOWLEDGEMENTS}

The authors would like to express their thanks to Brian McGee, Timmy O'Connor and all the staff at the Cork City and County Archives. We are also very grateful to the two anonymous reviewers and the Editor for helpful comments during the review process.

\section{ENDNOTES}

1 John H Bennett and Company, later John H Bennett and Company Limited.

2 The CSO StatBank database is located at http://www.cso.ie/en/databases/ and the Consumer Price Index (CPI) by year and selected base reference period was used to rebase the financial information in the annual accounts taking 1922 as a base year, and then Irish pound values have been converted to euros.

3 Under Section 350 of the Companies Act 2014, small company classification requires two of the following three criteria to be met: 1) a balance sheet total not exceeding €4.4 million, 2) turnover not exceeding €8.8 million, 3) number of employees not exceeding 50.

4 The Anglo-Irish Economic War, involving the Free State and Great Britain, took place between 1932 and 1938 , and consisted of 'default on intergovernmental debts, retaliation in the trade sphere escalating into an all-out trade war, and an eventual settlement implying victory for the defaulting nation' (O'Rourke, 1991:357).

5 The Cork Examiner, now called the Irish Examiner, although a national newspaper, has historically been strongest in the Cork area.

6 The IPM was the forerunner to the organisation currently known as the Chartered Institute of Personnel and Development (CIPD).

7 We do not detail the production control systems in this paper, but we have noted the high-quality malt produced, which is indicative of good production control.

8 Bennetts began to malt barley for the Park Royal brewery in January 1939, but by September 1939 there were shortages of malting barley owing to the Second World War.

9 The two malting businesses of Minch and P.R. Norton merged in 1921 to form Minch Norton. The company later changed its name to Minch Malt and is still in existence today.

10 This firm later became Magennis Burns Griffin \& Company in 1936 and later became part of Deloitte \& Touche, which is currently Deloitte.

11 The records do not provide an explanation of why the percentage dividend had changed.

12 The Civic Guard was established as the police force of the Irish Free State in 1922 and was renamed as An Garda Siochána in 1923.

13 The Royal Munster Yacht Club merged with the Royal Cork Yacht Club, the world's oldest yacht club, in 1966.

14 While it is not an exact comparison with the wage rates of both Bennetts and the Irish Maltsters' Association, the reported average weekly wage of wage employees (as distinct from salaried employees) of Guinness in 1930 was 83 shillings 4 pence (Dennison and MacDonagh, 1998).

\section{References}

\section{Primary Sources}

Archive of Bennett's of Ballinacurra, Cork City and County Archives, Cork.

Files utilised:

B609/1/A - Correspondence with Arthur Guinness \& Sons, 1901-1990

B609/1/B - General Letters, 1851-1989 (1826-29)

B609/1/D - Letters Received, 1900-70

B609/2/C - Barley Returns, 1907-39

B609/2/D - Production Control: Statistics (1926-90)

B609/2/J - Barley Purchases, 1909-76

B609/3/A - Cash Books, 1898-1971

B609/3/B - Journals, 1871-2002

B609/3/C - Ledgers, 1867-2000

B609/4/B - Directors' and Management Committee Minutes, Annual Reports, and related matter, 195193 (1929-42)

B609/4/C - Directors', Management, and Company Secretary's Correspondence, 1950-69 (1935-37)

B609/4/D - Company Statements of Account, and related matter, 1918-96

B609/5/A - Workmen's Agreements and Records of Service, 1917-2006

B609/5/B - Wages Books and Printouts, 1908-2000

B609/5/D - Wages Rates and Analyses, 1908-15; 193686
B609/5/E - Other Employee Records, c1908-2000

B609/9/A - John H Bennett Diaries and related items, 1881-1935.

Guinness Archive St. James's Gate, Dublin.

Files utilised:

Annual Reports, 1920 and 1935.

National Library of Ireland, Dublin.

Files utilised:

Newspaper archives, in microfilm holdings and in digital Irish Newspaper Archive.

\section{Secondary Sources}

Armstrong, J. (1991). 'An introduction to archival research in business history'. Business History, 33: 1, 7-34.

Central Statistics Office (2016). CPA04 Consumer Price Index by Year and Selected Base Reference Period (1922-2015), [Online]. http://www.cso. ie/px/pxeirestat/Statire/SelectVarVal/Define. asp? maintable $=$ CPA04\&PLanguage $=0$ [Accessed 31st May 2016].

Chandler, A.D. (1990). 'Response to the contributors to the review colloquium on scale and scope'. Business History Review, 64: 4, 736-758.

Chandler, A.D. (1994). Scale and Scope: The Dynamics of Industrial Capitalism, First paperback edition. Cambridge: Harvard University Press. 
Church, R. (1990). 'The limitations of the personal capitalism paradigm'. Business History Review, 64: 4, 703-710.

Church, R. (1993). 'The family firm in industrial capitalism: International perspectives on hypotheses and history'. Business History, 35: 4, 17-43.

Clark, C. (1998). The British Malting Industry Since 1830, London: The Hambledon Press.

Clarke, P. (1996). 'A glimpse at Irish accounting history'. Irish Accounting Review, 3: 2, 23-38.

Clarke, P. (2001). 'Financial reporting in Ireland - the period of independent isolation'. Irish Accounting Review, 8: 2, 23-43.

Colli, A., Howorth, C. and Rose, M. (2013). 'Long-term perspectives on family business'. Business History, 55: 6, 841-854.

Cork Examiner (1929). 'Maltsters' Dispute: Strike At Ballinacurra Works Settled', 8th January, p. 4.

Daly, M.E. (1992). Industrial Development and Irish National Identity, 1922-1939, Syracuse: Syracuse University Press.

Dennison, S.R. and MacDonagh, O. (1998). Guinness 1886-1939: From Incorporation to the Second World War, Cork: Cork University Press.

Drea, E. (2014). 'A gamble forced upon them? A reappraisal of Ulster Bank's operations in Southern Ireland 1921-32'. Business History, 56: 7, 1111-1128.

Gourvish, T.R. (1987). 'British business and the transition to a corporate economy: entrepreneurship and management structures'. Business History, 29: 4, 18-45.

Gourvish, T.R. (2006). 'What can business history tell us about business performance?'. Competition \& Change, 10: 4, 375-392.

Gourvish, T.R. and Wilson, R.G. (1994). The British Brewing Industry 1830-1980, Cambridge: Cambridge University Press.

Government of Ireland (2014). Irish Statute Book: Companies Act 2014, [Online]. http://www. irishstatutebook.ie/eli/2014/act/38/section/350/ enacted/en/html [Accessed 13th December 2016].

Griffiths, J. (1995). " "Give my regards to Uncle Billy...”: The rites and rituals of company life at Lever Brothers, c.1900-c.1990'. Business History, 37: 4, 25-45.

Gunnigle, P., Heraty, N. and Morley, M. (2002). Human Resource Management in Ireland, Dublin: Gill \& Macmillan.

Hiebl, M.R., Quinn, M. and Martínez-Franco, C. (2015). 'An analysis of the role of a Chief Accountant at Guinness c. 1920-1940'. Accounting History Review, 25: 2, 145-165.
Hopkins, F. (2009). 'The Man Behind The Black Stuff', Evening Herald, 17 $7^{\text {th }}$ September [Online]. http:// www.herald.ie/entertainment/the-man-behind-theblack-stuff-27925384.html.

Jeacle, I. and Walsh, E. (2008). 'A tale of tar and feathering: the retail price inventory method and the Englishman'. Accounting, Business \& Financial History, 18: 2, 121-140.

Jones, G. (1984). 'Multinational chocolate: cadbury overseas, 1918-39'. Business History, 26: 1, 59-76.

Kininmonth, K.W. (2006). 'The growth, development and management of J. \& P. Coats Ltd, c.1890-1960: An analysis of strategy and structure'. Business History, 48: 4, 551-579.

Loft, A. (1986). 'Towards a critical understanding of accounting: the case of cost accounting in the UK, 1914-1925'. Accounting, Organizations and Society, 11: 2, 137-169.

Lynch, P. and Vaizey, J. (1960). Guinness's Brewery in the Irish Economy 1759-1876, Cambridge: Cambridge University Press.

McCann, G. (2014). 'Protectionism and the "Economic War" in Interwar Ireland'. The Journal of European Economic History, 43: 3, 39-68.

McKinstry, S. and Ding, Y.Y. (2013). 'Alex Cowan \& Sons Ltd, Papermakers, Penicuik: a Scottish case of Weber's Protestant Work Ethic'. Business History, 55: 5, 721-739.

McWatters, C.S. and Lemarchand, Y. (2013). 'Merchant networks and accounting discourse: the role of accounting transactions in network relations'. Accounting History Review, 23: 1, 49-83.

Monks K. (1997). Roles in Personnel Management from Welfarism to Modernism: Fast Track or Back track? Research paper series, paper no. 17, Dublin: DCU Business School, pp. 1-24.

Neary, J.P. and Ó Gráda, C. (1991). 'Protection, economic war and structural change: the 1930s in Ireland'. Irish Historical Studies, 27: 107, 250-266.

Niven, M. (1967). Personnel Management 1913 - 63: The Growth of Personnel Management and The Development of The Institute, London: Institute of Personnel Management.

Ó Gráda, C. (1997). Rocky road: Irish Economy Since Independence, Manchester: Manchester University Press.

Ó hÓgartaigh C. and Ó hÓgartaigh, M. (2004). 'Accounting and corporate governance archives in Ireland'. Irish Accounting Review, 11: 1, 19-32.

Ó hÓgartaigh, M. (2008). 'Irish accounting, business and financial history: a bibliographical essay'. Accounting, Business \& Financial History, 18: 1, 7-19. 
O'Rourke, K. (1991). 'Burn everything British but their coal: The Anglo-Irish economic war of the 1930s'. The Journal of Economic History, 51: 2, 357-366.

Palmer, F.B. (1890). Private Companies, Their Formation and Advantages, $8^{\text {th }}$ ed., London: Stevens and Sons Limited.

Penrose, E.T. (2009). The Theory of the Growth of the Firm, 4th ed., Oxford: Oxford University Press.

Platt, J. (1981). 'Evidence and proof in documentary research: 1: Some specific problems of documentary research'. The Sociological Review, 29: 1, 31-52.

Pugh, D.S. and Hickson, D.J. (2007). Great writers on organizations: The Third Omnibus Edition, Aldershot: Ashgate Publishing Limited.

Quinn, J. and Leavy, B. (2004). 'Government activism and industry change: The structural evolution of Irish wholesaling'. Irish Journal of Management, 25: 1, 110-124.

Quinn, M. (2014). 'Stability and change in management accounting over time-A century or so of evidence from Guinness'. Management Accounting Research, 25: 1, 76-92.

Quinn, M. and Jackson, W. (2014). 'Accounting for war risk costs: management accounting change at Guinness during World War 1'. Accounting History Review, 24: 2-3, 191-209.

Scott, J. (1990). A Matter of Record: Documentary Sources in Social Research, Cambridge: Polity Press.

Silverman, D. (2013). Doing Qualitative Research, 4th ed., London: SAGE Publications Ltd.
Taff Vale Railway Company v. Amalgamated Society of Railway Servants (1901). United Kingdom House of Lords, AC 426, HL.

Talbot, P.A. (2006). 'The accounting history of the English brewing industry 1700-1939: An Exploration of Foucauldian Disciplinarity'. PhD thesis. Warwick: University of Warwick [Online]. Available at: http:// wrap.warwick.ac.uk/1182/ [Accessed 31 October 2016].

The Economist. (2014). The Economist Explains: Why Guinness Is Less Irish than you think, $16^{\text {th }}$ March [Online]. http://www.economist.com/ blogs/economist-explains/2014/03/economistexplains-13

Trade Disputes Act. (1906). United Kingdom (6 Edw. 7 c.47).

Walkden, C.H. (1891). 'The Accounts of a Brewery'. The Accountant, XVII: 862, 458-464.

Walsh, B. (2011). When the Shopping was Good: Woolworths and the Irish Main Street, Dublin: Irish Academic Press.

Walsh, E. and Jeacle, I. (2003). 'The taming of the buyer: the retail inventory method and the early twentieth century department store'. Accounting, Organizations and Society, 28: 7, 773-791.

West, T. (2006). Malting the Barley: John H. Bennett the Man and his Firm; 200 Years of Malting Barley in Ballinacurra, Cork: Charleston House.

Williamson, O.E. (1981). 'The modern corporation: Origins, evolution, attributes'. Journal of Economic Literature, 19: 4, 1537-1568. 